\title{
Sargassum Vegetation Growing in the Sea around Tsuyazaki, North Kyushu, Japan ${ }^{1}$
}

\author{
TAdaO Yoshida, ${ }^{2}$ TAKeO SAWAdA, and Masahiro HigaKi ${ }^{3}$
}

ECOLOGICAL STUDIES on the subtidal marine vegetation, including the Sargassum community, have not progressed far because it is harder to make field surveys in subtidal vegetation than in terrestrial or intertidal vegetations. Some depth records for species of marine algae have been obtained using dredges and other instruments. From these data, we know that there is considerable vegetation developed at subtidal depths (cf Uéda and Okada, 1938, 1940).

Walker (1947) carried out extensive studies of the Laminaria beds around Scotland. His attention has been centered chiefly on productivity. Underwater observation of seaweeds has been done from time to time in the course of the development of diving apparatus. Waern (1952) published the results of his underwater survey of seaweeds. More recently Gilmartin (1960) carried out a survey of the deeper water algae of Eniwetok Atoll with the aid of a self-contained underwater breathing apparatus (SCUBA). Above all, a work published by Gislen (1930) is the most remarkable. He proposed a system of classification of life-forms for benthic plants and animals, and described many "associations." When these works are examined from a phytosociological point of view it is noticed that they are prescribed by the state of progress in terrestrial plant ecology at the particular time of writing. For example, Gislen only recognized associations in the concept of Swedish school and based on data from but a few quadrats.

Artificial stone beds have been laid down on shallow bottoms at many places around Japan for the propagation of useful algae, such as

\footnotetext{
${ }^{1}$ Contribution from the Department of Fisheries, Faculty of Agriculture, Kyushu University. Manuscript received November 23, 1961.

${ }^{2}$ Tohoku Regional Fisheries Research Laboratory, Shiogama, Japan.

${ }^{3}$ Department of Fisheries, Faculty of Agriculture, Kyushu University, Fukuoka, Japan.
}

Gelidium and Undaria. In order to evaluate the usefulness of these artificial stone beds many surveys have been carried out on the communities of algae developed upon them. However, the data secured from them are too rough to provide satisfactory knowledge of the marine vegetation and succession in its populations (Katada, 1958).

Many concepts and methods for the analysis of vegetational structure have been proposed recently in the course of the development of phytosociology. In contrast to the method of classifying the plant communities used by Braun-Blanquet and others, Goodall (1953) introduced a new statistical method for classification using positive interspecific correlation between the species as a criterion. On the other hand, Whittaker (1956) and others developed the concept of a vegetational continuum. These are applicable to the study of marine algal vegetations.

A Sargassum vegetation covers large areas of the upper subtidal region of the warmer waters around Japan. This vegetation affords a good habitat or spawning bed to many kinds of fish. Plants of Sargassum and its allied genera, floating at the sea surface after being detached from their substrata, are known as "floating seaweeds" or "nagaremo." The floating seaweeds and many kinds of fish exist in a close relationship insofar as the fish spawning and growth of the larvae of the fish are concerned. The authors have been engaged in the survey of the floating seaweeds for several years, and feel acutely the necessity for knowledge concerning the Sargassum community from which the floating seaweeds of Japan are derived. The authors carried out a survey on the Sargassum community growing on the rocky shallow sea around Tsuyazaki, north Kyushu, Japan, and intend to analyse here the relationship of species populations to the gradient of environmental factors. 


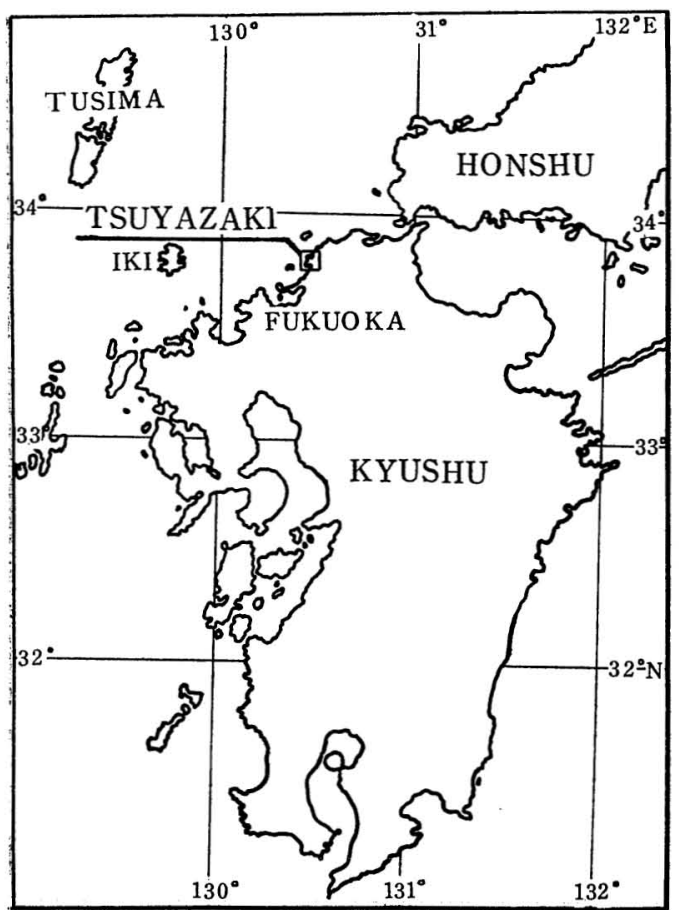

FIG. 1. Map of Kyushu, showing the position of Tsuyazaki.

\section{DESCRIPTTON OF AREA SURVEYED}

The peninsula of Tsuyazaki (Fig. 1) lies at $130^{\circ} 29^{\prime} \mathrm{E}, 33^{\circ} 47^{\prime} \mathrm{N}$, about $20 \mathrm{~km}$ northnortheast of Fukuoka City, and faces on the Genkai-nada. The peninsula protrudes from general coast line of sandy beach, and consists of hills more than $100 \mathrm{~m}$ high. Although these hills are for the most part composed of palaeozoic sedimentary rock, there is a granite zone on the west side facing the sea, and a basalt layer lying above the $100 \mathrm{~m}$ contour line. Along the middle of the shore of the peninsula, there is a sandy beach called "koi-no-ura." The rocky area, where the Sargassum community develops, occupies the northern and southern parts of the peninsula. An outline of the geological structure of the area concerned is shown in Figure 2.

Although the nature of the bottom is rocky where the shore is exposed to strong wave action from the intertidal zone to a depth of about $10 \mathrm{~m}$, or of boulders in more sheltered places, such hard bottoms give way to sand at the relatively shallow depth of $15 \mathrm{~m}$ or less. Sandy bottoms are met in deeper places all around the peninsula.

On the coast of North Kyushu, tides are semidiurnal, and the diurnal inequality of the tides is not remarkable. The spring tidal range is about $1.9 \mathrm{~m}$, and $1.4 \mathrm{~m}$ at neap tide. According to the "Coast of Kyushu Pilot" (1947), in the Kuraraseto passage, lying to the north-northeast about $10 \mathrm{~km}$ from Tsuyazaki, the tidal current flows towards the north from $4 \mathrm{hr}$ after low tide to $4 \mathrm{hr}$ after high tide, and towards the south from $4 \mathrm{hr}$ after high tide to $4 \mathrm{hr}$ after low tide. The tidal current flowing north reaches a speed of 2.8 knots. Near the shore of the area surveyed, the tidal current runs even faster around Tsuzumi islet, lying to the north of the peninsula, and may reach a maximum speed of more than 1 knot. The current moves more slowly near Sone-no-hana and Kyôdomari.

Stronger waves and swells are generated with north or west winds, influenced by the topography of the neighbouring area. Hence, the north and west sides of the peninsula are more ex-

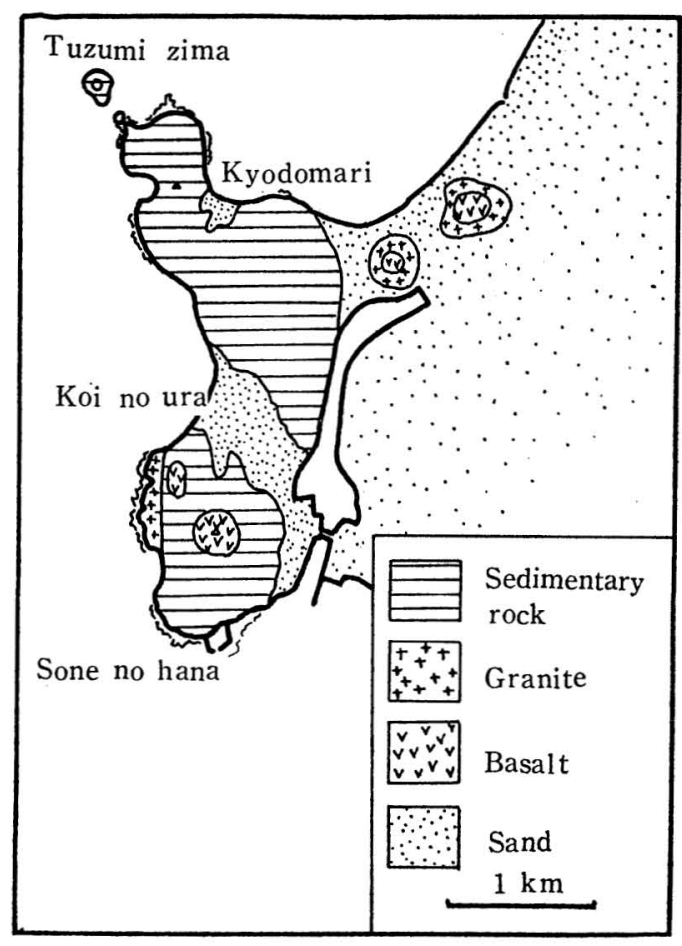

FIG. 2. Geological map of the peninsula of Tsuyazaki (after Takehara, 1937). 


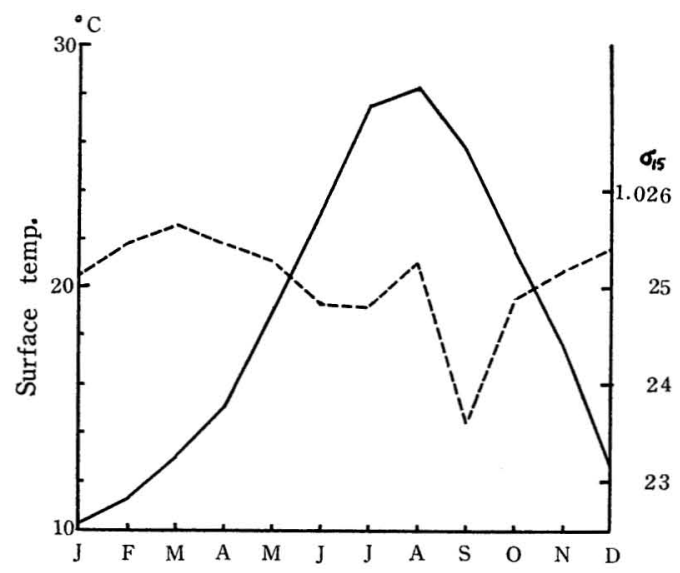

FIG. 3. Seasonal variation of surface temperature (solid line) and specific gravity (dotted line) of the sea water for 1960 , measured at the top of the breakwater for the port of Tsuyazaki.

posed to wave action. The eastern sides of Soneno-hana and Kyôdomari are more sheltered from wave action, although there is no method of determining the strength of wave action, judging from the results of direct observation of waves and from the characteristics of the intertidal algal zonation.

The tidal current is faster where the shore is more exposed to wave action, and vice versa in the area surveyed.

Surface temperatures rise to about $28 \mathrm{C}$ in August and descend to about $10 \mathrm{C}$ in January (Fig. 3). Transparency of the sea water is less than $15 \mathrm{~m}$ in the Secchi disc reading almost throughout the year. After a heavy rain, low transparency is sometimes recorded around Sone-no-hana.

\section{METHODS}

Field surveys were carried out during 7 days between July 23 and August 26, 1959, on 13 survey lines in the area (Fig. 4), as follows. A survey ship was anchored at the offshore end of each line. A rope was then strung from the ship to a rock on the shore. Survey spots were selected along the rope every 5 or $10 \mathrm{~m}$ depending on the inclination of the bottom. One or two observers, a recorder, and a crew got into a small boat. The boat halted at each survey spot. The depth of water was measured with a sound- ing lead and then a quadrat was laid down. The quadrat used in this study was a $0.5 \mathrm{~m}$ square iron frame. Observations on the plants found in the quadrat were made by skin diving, using a face mask only. First, the percentage of vegetational cover of the area around the quadrat was recorded. Then, the degree of cover by each species of the algae present in the quadrat was measured. The scale for the measurement of cover degree was as follows:

$$
\begin{array}{rr}
+ & 0-10 \% \\
1 & 11-20 \% \\
2 & 21-40 \% \\
3 & 41-60 \% \\
4 & 61-80 \% \\
5 & 81-100 \%
\end{array}
$$

Number and height of the plants were recorded when this was possible. The species not present in the quadrat but found in the surrounding area were also noted.

The number of quadrats placed along each

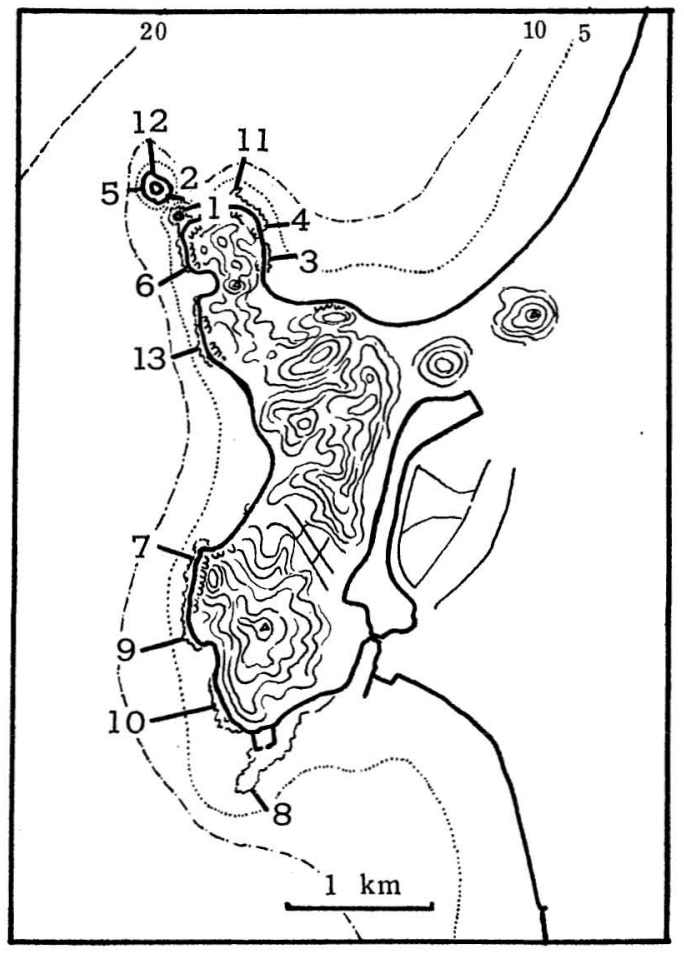

FIG. 4. Map of Tsuyazaki peninsula, indicating the 13 survey lines. 
survey line varied from 10 to 20 , according to the inclination of the bottom; 197 sets of quadrat data were obtained. All data needed for analysis were recorded on hand-sort edgepunched cards to facilitate the compilation of the data. Readings of depth were adjusted to the low watermark of spring tide, and the quadrat of $0 \mathrm{~m}$ level indicates the quadrats placed above the low watermark. The depth represented as 1 $\mathrm{m}$ concerns the quadrat level laid down between low watermark and $1 \mathrm{~m}$ deep, and so on.

\section{RESULTS}

\section{Stratal Structure of Sargassum Community}

Twelve species of Sargassum, one species of Cystopbyllim, and one species of Hizikia occurred in the quadrats surveyed (Table 1). The fruiting period of these species is revealed by analysing the data obtained from surveys of the floating seaweeds (Segawa, Sawada, Higaki, and Yoshida, 1959). According to these results and our observations made at the stations investigated, all of the species growing there except Sargassum ringgoldianum had passed their fruiting period. Most of the individuals of each perennial species had lost their long branches bearing the receptacles, and most of the branches of the next year class had reached a length of $30-40 \mathrm{~cm}$. Therefore, the vegetation was at its lowest height for the year. However, $S$, ringgoldianum was taller than the rest. Annual

\section{TABLE 1}

SPECIES OF Sargassum AND ReLATED GeNerA OBSERVED IN QUADRATS

S. thunbergii (Mertens) O. Kuntze

S. nigrifolium Yendo

S. bemiphyllum C. Agardh

S. confusum Agardh

S. micracanthum (Kützing) Yendo

S. ringgoldianum Harvey

S. fulvellum Agardh

$S$. patens C. Agardh

S. tortile C. Agardh

S. yendoi Okamura et Yamada?

S. piluliferum C. Agardh

S. serratifolium J. Agardh

Cystopbyllum sisymbrioides J. Agardh

(= Myagropsis myagroides (Turner) Fensholt)

Hizikia fusiforme (Harvey) Okamura species such as $S$. borneri were in a very early stage of growth. At the time of the year when the survey was done, therefore, all species of Sargassum were considered to contribute to the same layer, and cover degree of the species was rather easy to determine. Stratal difference may be developed among the species of Sargassum during the period from winter to spring, because of the difference in the growing and fruiting periods of the species concerned ( $\mathrm{cf} \mathrm{Se}$ gawa, Sawada, Higaki, and Yoshida, 1960). Species other than Sargassum occurred mainly at shallower places, and there was almost the total lack of a frondose lower layer under the well-developed layer of Sargassum. The crustose layer was represented by species of unarticulated corallines. In the area where the upper layer was open because of the absence of Sargassum, several species of frondose algae other than Sargassum formed a lower layer. Although the population of Sargassum became sparse in deeper places, the society of the lower frondose strata was not developed. This fact may be attributed partly to the survey time, when many kinds of algae were extremely depauperate in growth for the year.

\section{Vertical Distribution of Species}

The substratum profile and the vertical distribution of some of the major species of Sargassum are presented (Fig. 5) for each station.

At station 1(Fig. 5), the rocky bottom is evenly sloped to a depth of more than $8 \mathrm{~m}$, then it gives way to sand. The dominant species of Sargassum changes with increasing depth: S. piluliferum is predominant at depths less than $3 \mathrm{~m}$, then $S$. patens predominates over the other species on rock surfaces about $3 \mathrm{~m}$ deep, and finally $S$. serratifolium predominates in deeper places. On the other hand, at station 6 (Fig. 5), the bottom is of boulders for the most part and there is some solid rock bottom in places. The slope of the bottom is lower than at station 1. While three of the species of Sargassum just mentioned are also present here, their degree of cover and vertical range do not coincide with what was found at station 1 . As stated above, the vertical ranges of the species are not the same among the stations surveyed. An explanation for these differences is desirable. 

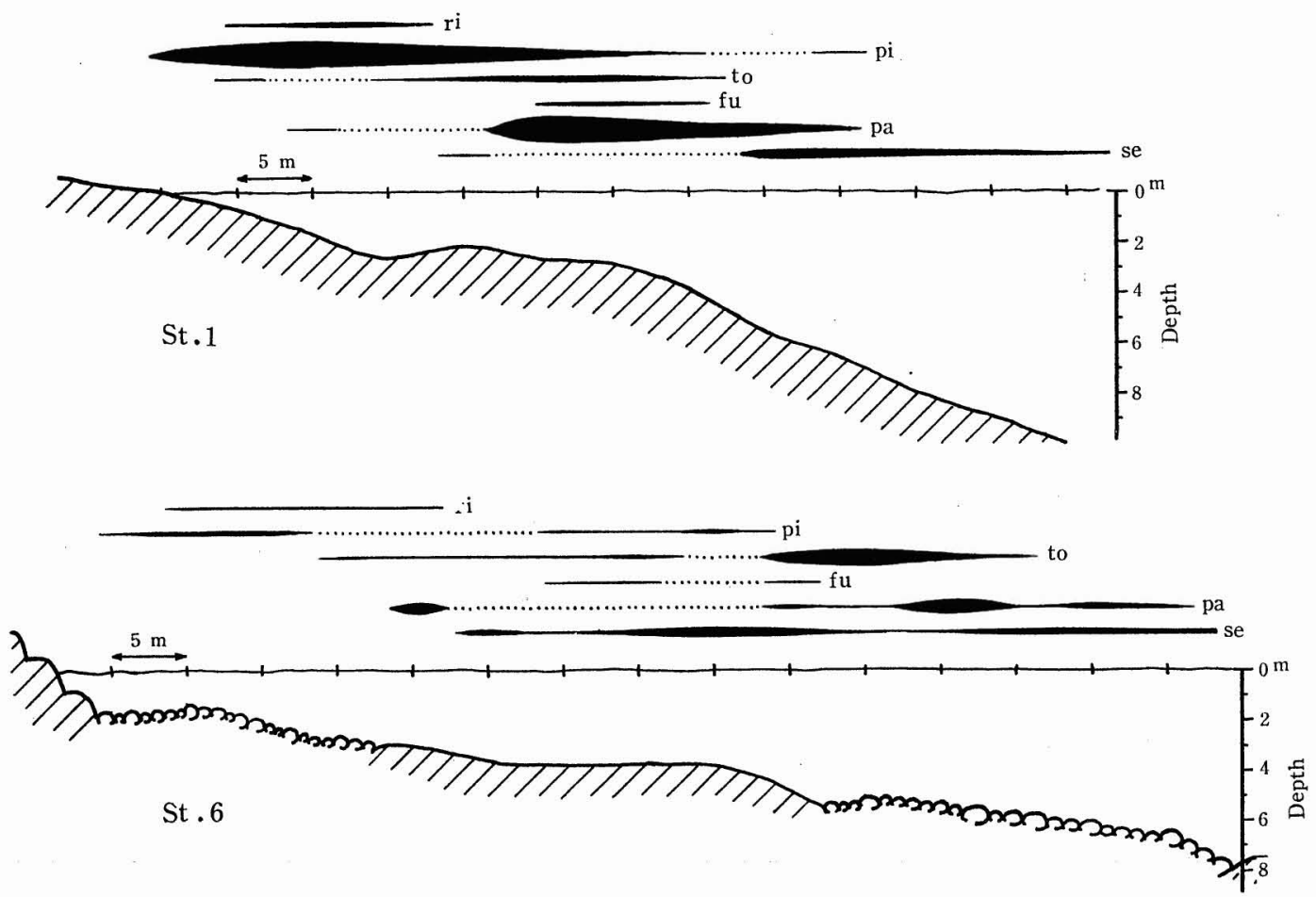

Fig. 5. Profile of substratum and distribution of species: ri, S. ringgoldianum; pi, S. piluliferum; to, S. tortile; fu, $S$. fulvellum; pa, $S$. patens; se, $S$. serratifolium.

\section{Vegetational Cover}

The percentage of vegetational cover was approximated by eye for several square meters around the spot where the frame of the quadrat was laid down. For this measurement, crustose algae were not included. As shown in a later section, algae other than Sargassum were found mostly in the relatively shallow places and had only a slight effect on the degree of vegetational cover in the deeper places.

Variation in average vegetational cover with increasing depth was determined using the whole quadrat samples. This mean value is indicated with a dotted line in Figure 6. From this figure it can be seen that the average vegetational cover is nearly uniform from the low watermark to $5 \mathrm{~m}$ deep, and then decreases gradually in places beyond the $5 \mathrm{~m}$ depth. Here only depth of water is taken into consideration as an environmental factor.

In this study, the 13. stations surveyed are placed in three groups according to the strength of wave action. For each of the three groups, then, the relationship between the depth of water and average vegetational cover is plotted in Figure 6 by the three solid lines. At the rather sheltered stations subject to weak wave action, the maximum value for average vegetational cover is found at the $1 \mathrm{~m}$ depth. As deeper water is reached the values fall quickly. For the areas where wave action is moderate, vegetational cover reaches its maximum $2-3 \mathrm{~m}$ below low watermark and gradually decreases with increasing depth. An examination of the values from the stations exposed to the strongest wave action shows the values for average vegetational cover reach $100 \%$ above the low watermark, then fall and again come to a peak at the depth of 4-6 m. Algae other than Sargassum contribute to the vegetational cover in shallower places exposed to strong wave action. Therefore, when the degree of cover for Sargassum only is considered, the depth at which the maximum value for vegetational cover is found becomes deeper with increasing strength of wave action. 


\section{Distribution of Species Populations along Environmental Gradient}

The distribution pattern of the populations of Sargassum may not be understood when only the depth of water is taken into consideration as an environmental factor. The effect of the wave action on it must be considered at the same time. The survey stations are classed in three groups according to the degree of wave action, as shown above. Average degree of cover of each species is plotted against depth. For five major species, the curves of average degree of cover were superimposed to obtain the graph represented by Figure 7. The curve for each individual species overlaps the others and the peaks of the different curves occur at different depths. For the places moderately exposed to wave action (Fig. 7, lower graph), the curve for $S$. hemiphyllum has its peak at a depth of $1 \mathrm{~m}$ below low watermark, that of $S$. ringgoldianum comes second, and next in order are $S$. piluliferum, $S$. patens, and $S$. serratifolium, from the shallowest to the deepest. In places subjected to stronger wave action (Fig. 7, upper graph), the order of appearance is the same as above, but the peaks of the curves for degree of cover occur deeper, except in the case of $S$. ringgoldianum.

The method of gradient analysis developed

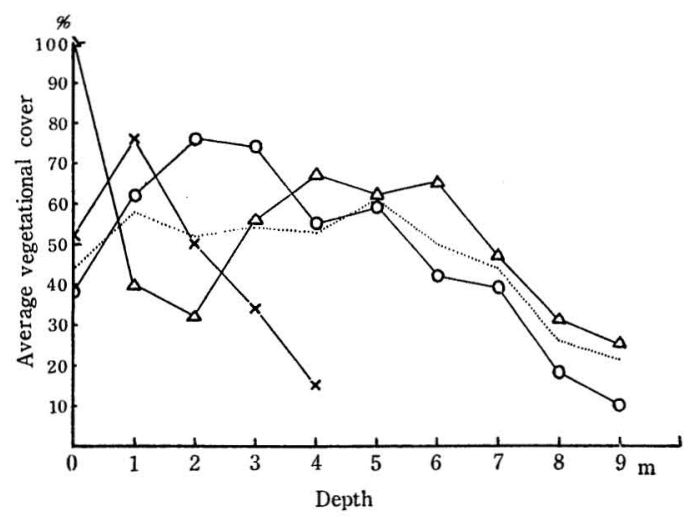

FIG. 6. Variation of average vegetational cover in relation to depth of water.

$$
\begin{aligned}
& \mathrm{X} \ldots \ldots \text { Average of whole quadrat data } \\
& \mathrm{O}-\mathrm{X} \text { Sheltered } \\
& \Delta \longrightarrow \Delta \text { Exposed }
\end{aligned}
$$

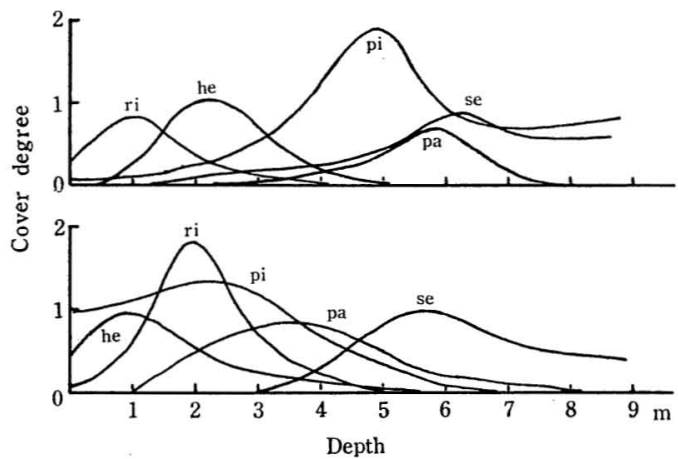

FIG. 7. Change of cover degree in relation to depth of water. (Abbreviation of species names as in Fig. 5.)

by Whittaker (1956) is introduced here to make the distribution pattern of these Sargassum species more clear. The depth of water and exposure to wave action are considered as the principal environmental gradients. The population nomograms for six major species constructed on this basis are shown in Figure 8. $S$. serratifolium, $S$. piluliferum, and $S$. hemiphyllum have their peaks at the stations exposed to stronger wave action, but their peaks occurred at different depths, in the order given, with $S$. bemiphyllum at the shallower end of the series. The species which occurred more abundantly at the places subject to more moderate wave action are $S$. ringgoldianum and $S$. fulvellum. The former grows more abundantly at places of $2 \mathrm{~m}$ depths where the bottom is hard and wave action is moderate. It has a tendency to grow in shallower places with both increasing and decreasing strength of wave action. This bimodal distribution pattern is peculiar to this species only. Only young individuals of $S$. fulvellum, an annual species, were found when the investigation was carried out, and the degree of cover of this species was very low. Nevertheless a population nomogram of distinctive pattern was obtained. $S$. patens and $S$. tortile grow abundantly on bottoms more sheltered from wave action. However, the population nomogram for one species differs more or less from the others in the position of maximum value, even if the distribution patterns are similar to each other. Generally speaking, most species of Sargassum grow in deeper places as the strength of the wave action increases. 


\section{Objective Classification of Sargassum Commu- nity}

Goodall (1953) proposed a method of dividing vegetation samples into statistically homogeneous groups. This method involves preparing a $2 \times 2$ table whereon the correlation between every pair of species is analysed by computing a value from the number of quadrats in which one or both of two particular species are present or not. An objective classification can be arrived at when, with respect to all species growing in the sample quadrats, no interspecific correlations of significant level occur within each group of quadrats, so that the quadrats may be divided into some homogeneous groups. The significance of interspecific correlation is decided by $\chi^{2}$ test, preparing the $2 \times 2$ table, as shown below:

\begin{tabular}{|c|c|c|c|c|}
\hline \multirow{2}{*}{\multicolumn{2}{|c|}{. }} & \multicolumn{2}{|c|}{ SPECIES B } & \\
\hline & & \multirow{2}{*}{ 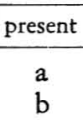 } & \multirow{2}{*}{$\begin{array}{c}\text { absent } \\
\text { c } \\
\text { d }\end{array}$} & \\
\hline Speciès A & $\begin{array}{l}\text { present } \\
\text { absent }\end{array}$ & & & $\begin{array}{l}a+c \\
b+d\end{array}$ \\
\hline & & $a+b$ & $c+d$ & $\mathrm{n}=\mathrm{a}+\mathrm{b}+\mathrm{c}+\mathrm{d}$ \\
\hline
\end{tabular}

$$
\chi^{2}=\frac{(a d-b c \pm n / 2)^{2} n}{(a+b)(c+d)(a+c)(b+d)}
$$

Values of $\chi^{2}$ are calculated between every pair of the six species of Sargassum contained frequently in quadrats, and are shown in Table 2. Only two combinations, i.e., the pairs of $S$. ringgoldianum-S. piluliferum and $S$. tortile-S. patens, have significant correlation at the $5 \%$ level. According to the first procedure of classification proposed by Goodall (1953: 46-50), as a result of the elimination of quadrats containing one species of high frequency in those four species mentioned above, no species was found which has a significant interspecific correlation with the others in the final two groups obtained. However, the two groups obtained from this procedure are not useful because quadrats belonging to one group are considerably intermixed with the others.

\section{Distribution of Algae Other than Sargassum}

Although attention was not centered on the distribution of algae other than Sargassum, observational data on those algae were recorded as often as possible. The species observed in this survey are listed in Figure 9. The frequency of quadrats containing algae other than Sargassum is calculated for each depth, and the graph in Figure 10 is the result. This graph illustrates that the species other than Sargassum occurred in all quadrats laid above the low watermark, but that the frequency of their occurrence in quadrats decreases sharply with increasing depth. The range of the species growing at different depths is shown in Figure 9. Dictyopteris undulata was observed in the deepest quadrat. The marine vegetation was richest in number of species at the place exposed to the strongest wave action, and more abundant in number of individuals near the low watermark. At deeper places the density of algae is less and the vegetational cover may be provided by the species of Sargassum alone.

\section{DISCUSSION}

With respect to the stratal structure of the marine algal community, Segawa considered that three layers are recognized, i.e., the upper, lower, and crustose layers, when a well-developed vegetation is being considered (Katada, 1958). The upper layer is more than $10 \mathrm{~cm}$ in height, and the crustose layer is composed of algae less than $1 \mathrm{~cm}$ high. At the time of the year when

TABLE 2

$\chi^{2}$ - VAlues betWeEN Six SPECIES OF Sargassum Frequently ENCOUNTERED

\begin{tabular}{l|c|c|c|c|c}
\hline \hline & S. bemiphyllum & S. piluliferum & S. ringgoldianum & S. tortile & S. patens \\
\hline S. serratifolium & 6.093 & 2.652 & 4.330 & 2.923 & 1.661 \\
S. patens & 0.517 & 7.337 & 6.391 & 8.405 & \\
S. tortile & 2.527 & 0.045 & 0.000 & & \\
S. ringgoldianum & 2.197 & 9.776 & & & \\
S. piluliferum & 3.772 & & & & \\
\hline
\end{tabular}



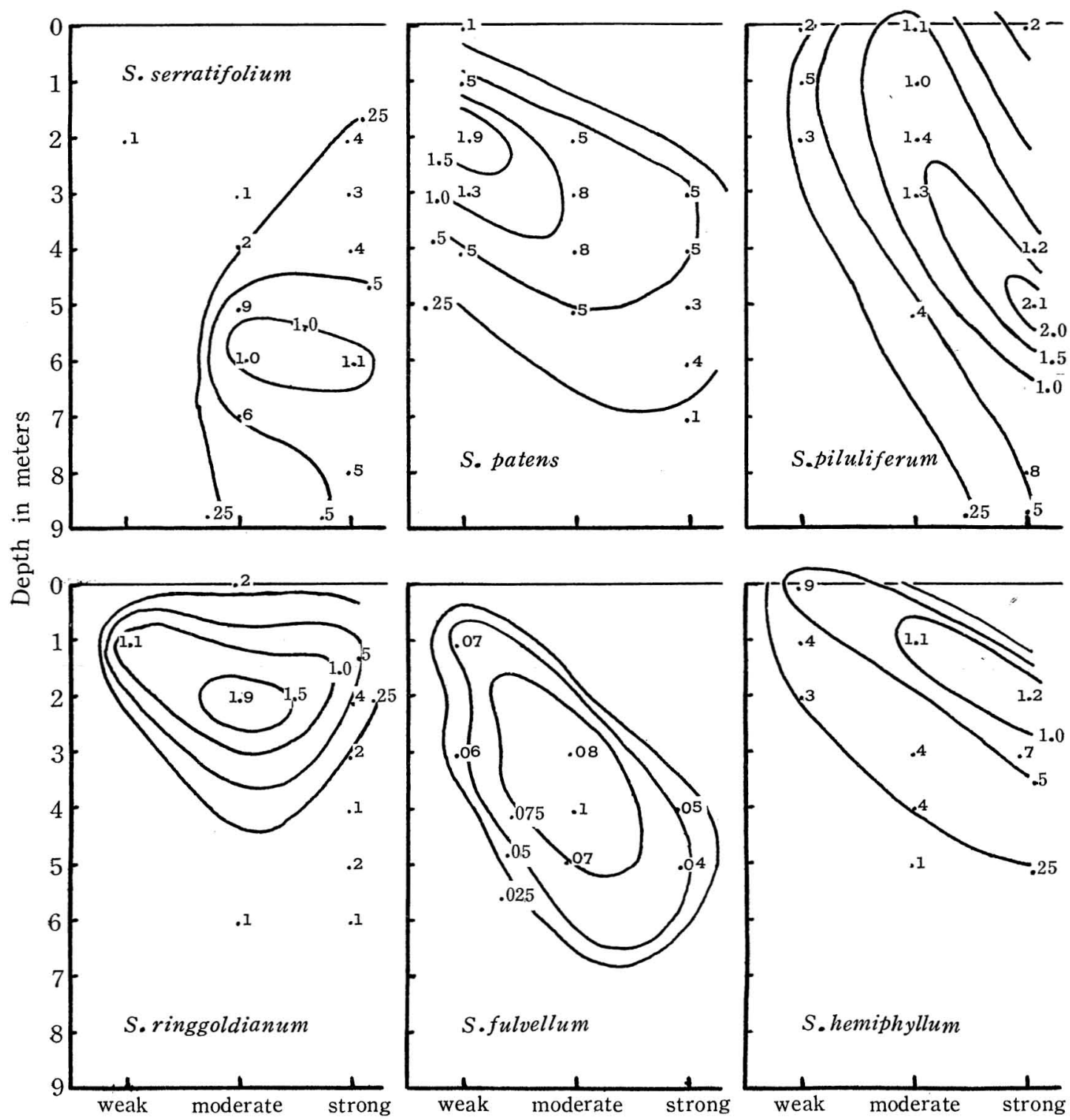

S. patens
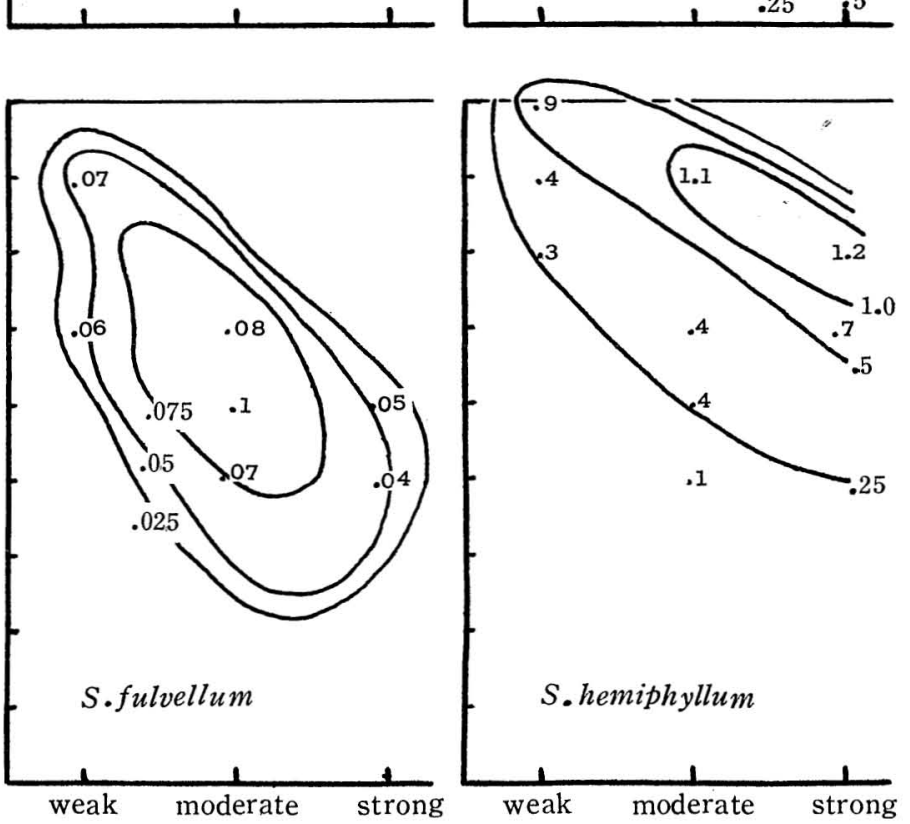

Wave action

FIG. 8. Population nomograms for six major species of Sargassum.

this survey was made, all the species of Sargassum found in the subtidal region formed but a single upper layer, and there was no constituent in this layer other than Sargassum. Katada reported that Undaria pinnatifida may also be included in this layer, intermingled with Sargassum.
As already pointed out, in reference to the population nomograms in Figure 8, the Sargassum community appears to form a continuum. This is confirmed by the application of Goodall's objective method of classification. Hence it is desirable that our attention be centered on the distribution of each species popu- 
lation in relation to the gradient of environmental factors, rather than centering it on classifying the communities.

The junior author has reported that the vertical distribution of a species of Sargassum is hardly explained when only the depth of water is taken into consideration, and that, in addition, presence or absence of a species at a certain station may partly be determined by the degree of exposure to wave action (Yoshida, 1961). At present, our knowledge is insufficient to elucidate the detailed effect of many environmental factors on the distribution of the species. For marine plants, increasing the depth of water has an important effect on growth in connection with the diminishing intensity and variation in the spectrum of the light penetrating into the water. On the other hand, we must take into account the other environmental factors, such as wave action or the turbulence of water. There is also a resultant complex of several factors. According to Gessner (1955: 198-209), the movement of water may have a close relationship with the assimilation and respiration rates of marine algae. It has already been re-

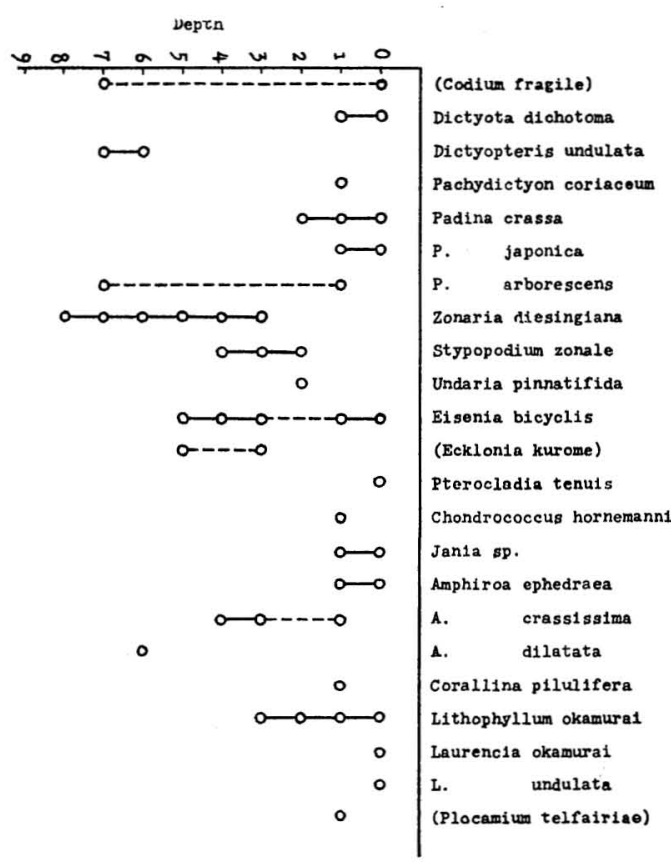

FIG. 9. Vertical ranges of distribution of algae other than Sargassum. Species in parenthesis did not occur in quadrats.

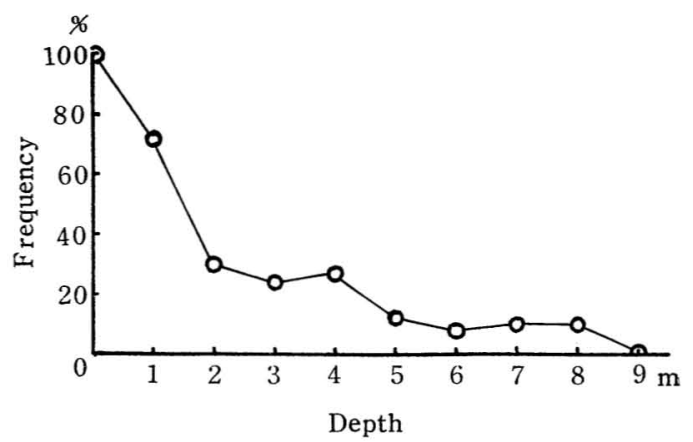

FIG. 10. Frequency in occurence of algae other than Sargassum (cf Fig. 9) in relation to water depth.

ported that the distribution pattern of intertidal organisms is greatly affected by the turbulence of water (Southward and Orton, 1954). In this present study the distribution pattern of the species of Sargassum is clearly shown by the two-dimensional gradient analysis improved by Whittaker (1956). Two principal environmental gradients considered here are (a) the depth of water, and (b) the exposure to wave action. In the area surveyed the tidal current is faster where the shore is exposed to the stronger wave action, as stated above. It is hardly possible to treat the two factors, namely, exposure to wave action and speed of tidal current, independently.

Determining the lower limit of the marine vegetation was prevented by the diving ability of the observer. It is observed around Tsuzumi islet that the species of Sargassum grow at places deeper than $10 \mathrm{~m}$, where hard bottoms are found. At most of the stations, the hard bottom gives way to sand before what would seem to be the lower potential limit for Sargassum growth is reached.

\section{SUMMARY}

The Sargassum community found in the upper part of the subtidal region in the sea around Tsuyazaki, North Kyushu, Japan was studied phytosociologically in July and August, 1959. It seems that this community can not be divided successfully into smaller groups by applying Goodall's objective method of using positive interspecific correlation. The gradient analysis method developed by Whittaker (1956) 
was applied here to the major species of Sargassum. Two principal environmental gradients considered here are depth of water and exposure to wave action. The stratal structure of this community is also noted.

\section{ACKNOWLEDGMENTS}

The authors wish to express their sincere appreciation for the guidance of the late Professor S. Segawa throughout this study. Their heartiest gratitude is due Professor T. Hosokawa, of the Faculty of Science, Kyushu University, and to Professor Maxwell S. Doty, of the University of Hawaii, for their kind advice and criticism of the manuscript. The authors' thanks are also due Mr. T. Furukawa in the Fishery Research Laboratory, Kyushu University, who assisted them in the course of the field survey.

\section{REFERENCES}

Gessner, F. 1955. Hydrobotanik, Bd. I. Deutscher Verlag, Berlin. 517 pp., 291 figs.

Gilmartin, M. 1960. The ecological distribution of the deep water algae of Eniwetok Atoll Ecology 41(1): 210-221.

GisLEN, T. 1930. Epibioses of the Gullmar Fjord II. Skrifts. K. Svensk. Vetensk. Kristenbergs Zoo. Stat. 4: 1-380.

GoODALL, D. W. 1953. Objective methods for the classification of vegetation, I. The use of positive interspecific correlation. Austral. J. Bot. 1(1): 39-63.

Katada, M. 1958. Phytosociological consideration on the artificial stone beds for Undaria pinnatifida. Aquiculture 5(3): 30-39. [In Japanese.]

MARITIME SAFETY BOARD. 1947. Coast of Kyushu Pilot. Tokyo. 338 pp.
Segawa, S., T. SAwAdA, M. Higaki, and T. YosHIDA. 1959. Studies on the floating seaweeds, III. Some considerations on the formation of the floating seaweeds. Sci. Bull. Fac. Agr., Kyushu Univ. 17(3): 299-305. [In Japanese.]

1960. Studies

on the floating seaweeds, IV. Growth of some sargassaceous algae based on the material secured from floating seaweeds. Sci. Bull. Fac. Agr., Kyushu Univ. 17(4): 429-435. [In Japanese.]

SOUTHWARD, A. J., and J. H. ORTON. 1954. The effect of wave-action on the distribution and number of the commoner plants and animals living on the Plymouth breakwater. J. Mar. Biol. Ass., U. K. 33 (1) : 1-19.

TAKeHARA, H. 1937. Geology of the Tsuyazaki area, Fukuoka Prefecture. Mem. Fac. Tech., Kyushu Univ. 12(5): 263-276. [In Japanese.]

UedA, S., and Y. OKadA. 1938. Studies on the vegetation of the marine algae in the seas of Japan, with special reference to the depth of the growing zone. Bull. Jap. Soc. Sci. Fish. $7(4)$ : 229-236. [In Japanese.]

1940. Studies on the vegetation of the marine algae in the seas of Japan, with special reference to the depth of the growing zone (II). Bull. Jap. Soc. Sci. Fish. 8(5): 244-246. [In Japanese.]

WAERN, M. 1952. Rocky-shore algae in the Öregrund Archipelago. Acta Phytogeogr. Suecica. 30: 1-298.

WALKeR, F. T. 1947. Sublittoral seaweeds survey. J. Ecol. 35 (1-2) : 166-185.

WHITTAKER, R. H. 1956. Vegetation of the Great Smoky Mountains. Ecol. Monogr. 26: $1-80$.

Yoshida, T. 1961. A brief study on the Sargassum vegetation around Ushibuka, west Kyushu, Japan. Jap. J. Ecol. 11 (5): 191-194. [In Japanese.] 